\title{
THE WHITE RIGHT
}

\section{A threat to South Africa's internal security?}

Martin Schönteich, Institute for Security Studies

martin.s@iss.co.za

In late 2002 a number of bomb blasts brought home the realisation that the South African white right did not disappear after the 1994 election. The police have made a number of arrests and seem to have stopped the bombings - for now. The white right cannot garner the support necessary to execute a succesful coup in South Africa. However, given sufficient backing, the extreme white right could maintain a sustained sabotage campaign and impair South Africa's international image while damaging race relations in the country.

$\mathrm{J}$ ust after midnight on 300 ctober 2002 eight bombs rocked Soweto, South Africa's largest township. Seven of the blasts destroyed commuter railway lines running through the township, inconveniencing more than 200,000 commuters. The eighth blast occurred at a mosque, causing parts of the building to collapse. A hitherto unknown organisation, Die Boeremag (Boer force/power) claimed responsibility for the bombings.

During 2002 almost two dozen alleged Boeremag members - including serving military officers were arrested and charged with terrorism-related offences, sabotage and high treason. After uncovering a Boeremag weapons cache, the national commissioner of police, Jackie Selebi, revealed that there were about 100 key Boeremag members in the country, many of whom have access to defence force weapons. Selebi pointed out that most of the suspects were young - between the ages of 17 and 40 years - and that many of the suspects were qualified professionals and prosperous farmers.

South Africa's industry, wealth and human capital are concentrated in a few metropolitan areas. A number of powerful bombs, strategically placed, could cause considerable harm to South Africa's fragile economy. Alternatively, the assassination of a handful of cabinet ministers and popular black political or religious leaders could take the country to the brink of a race war.

\section{Before 1994}

In order to evaluate the threat the white right poses to South Africa's internal security, it is vital to understand the historical context in which the white right - and more particularly the Afrikaner right came about. The emergence of the contemporary white right must be understood against the background of the rise of Afrikaner nationalism in the twentieth century. Throughout their history Afrikaner nationalists believed that the only way to protect the status and identity of the Afrikaner, and to prevent the group from being dominated by other ethnic groups or races, was to exercise power through self-determination in an ethnically homogenous territory. ${ }^{1}$

A significant weakness of the white right is its internal divisions on issues of policy and strategy, and personality-driven differences. N otwithstanding such divisions, however, Afrikaner nationalists argue that they share three common ethnic attributes: the Afrikaans language, Calvinist religion, 
and Afrikaner history, with its claim to an own territory or volkstaat (people's state). W hile race is not specifically mentioned as an attribute, it is implied in the understanding the Afrikaner right has of ethnicity. ${ }^{2}$

In the late 1980s the white right had significant support among Afrikaners. In the 1989 election the white right enjoyed the support of the majority of Afrikaners in the then Transvaal and O range Free State provinces. In 1992 close to a million white South Africans voted against sharing political power with black people at central government level (Figure 1). on the fringes of the white right. The most significant of these have been the actions of the Boeremag. The unexpected appearance of the Boeremag means that there are groups of hardcore right-wingers who are tenaciously devoted to creating an Afrikaner state.

The story of the Boeremag makes a fascinating case study of how the extreme right mixes religion and politics. The Boeremag's sabotage campaign was driven by a philosophy based on extreme nationalist views and a sense of God-given purpose: a lethal cocktail, given the damage religiously inspired terrorism has caused in other parts of the world.

Figure 1: Number of votes received by the white right, 1970-1999

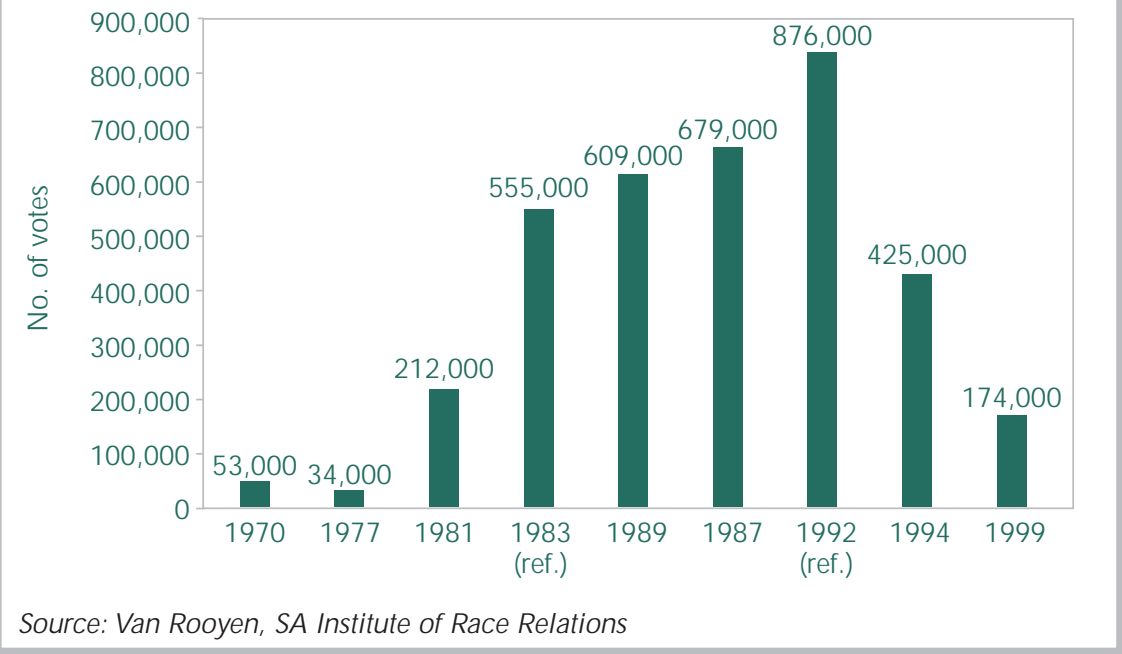

It is apparent from documents confiscated from alleged Boeremag members that the organisation is motivated by prophecies made in the early twentieth century by a Boer seer, $\mathrm{N}$ icolaas van Rensburg. Indeed, there are strong indications that the insurrectionist plans of the Boeremag were at least partly motivated by Van Rensburg's prophecies.
In the run-up to the country's first democratic election based on universal adult suffrage in 1994, the white right arguably had the capacity to push the country into a civil war and unilaterally establish an exclusive white, Afrikaner volkstaat in a part of South Africa.

In the post-1994 era most right-wing whites, disillusioned by the political impotence of right-wing organisations and leaders, have withdrawn from political activity. Some try to withdraw from the realities of the new South Africa by moving into gated communities. $O$ thers - especially the younger generation - are emigrating.

\section{Appearance of the Boeremag}

However, a few isolated, but significant, violent incidents after 1994 reveal that there is some activity
Van Rensburg predicted the coming into power "of a black government", but that this would be of a short duration only. During this time, "hostility from Indian ranks reaches a crisis over the Afrikaans language... the language of the Boers and everything connected with it is now being denied and trampled upon. All the protests of the Boer fall on deaf ears." Van Rensburg further said "a day will come when the Indians will occupy positions of power in the country. The Christian values of the Afrikaner will then be in direct conflict with the religion of Islam." ${ }^{3}$

The Boeremag makes a good case study, for another reason. Initially underestimated by the police and the intelligence community, the danger posed by the organisation grew to become South Africa's primary security threat in late 2002. 
The police successfully identified and arrested key Boeremag suspects, bringing to a halt the bombing campaign before it resulted in any major loss of life. The police's success was largely based on good intelligence work. With these arrests the police seriously disrupted the plans of the Boeremag. However, if the Boeremag is organised in a cell-like structure (which seems likely), it is probable that some individual cells have gone unnoticed by the police.

\section{Mobilising support}

The number of extreme right-wingers who are prepared to use violence to achieve their aims is likely to be small, and unlikely to ever engender the active participation of most Afrikaners. It is a sobering fact, however, that for a sabotage campaign to be successful and create long term instability, this is not necessary. At the height of its activities the Irish Republican Army (IRA) had no more than a few hundred active members. The secret of the IRA's success was that it had a large number of sympathisers who provided the organisation with logistical support. In South Africa a small group of right-wing saboteurs will be difficult to apprehend if they are viewed sympathetically by Afrikaners in general.

A confiscated Boeremag document reveals how the organisation seeks to give a populist spin to its activities. The document cites post-1994 levels of crime, unjust affirmative action policies, and the sidelining of the Afrikaans language as reasons why an independent Afrikaner state is justified. Given the current high levels of violent crime, rising white unemployment, and the state-sponsored campaign against farmers in neighbouring Zimbabwe, such arguments may be capable of eliciting widespread sympathy among conservatively-minded Afrikaners.

M oreover, under certain circumstances, and with a right-wing organisation capable of exploiting popular Afrikaner grievances, it is possible that a right-wing sabotage campaign could be condoned and even tacitly supported - by a significant number of Afrikaners.

The state needs to guard against alienating the broader ethnic community in which the white right operates. The white right should not be allowed to succeed in creating martyrs whose 'suffering' and 'sacrifices' can be idealised and used to enlist new impressionable young recruits.

Supposing conservative Afrikaners did support the state's fight against right-wing saboteurs, this support could rapidly be undermined in the event of security force excesses. The perception can then be fostered that the security forces (and by implication the government), are victimising members of the ethnic group in general. With time, and depending on the extent of the abuses, a significant number of Afrikaners, and not only rightwing extremists, may begin to view the security forces as the real enemy. O nce this happens a small but substantial number of Afrikaners may stop cooperating with law enforcement agencies, and even develop sympathies for the extremists amongst them.

There are already allegations that Boeremag suspects have been tortured by the police. According to press reports a homeless white man was mistakenly arrested in connection with the Soweto Boeremag bombings. The man alleges that the police tortured him, which included giving him electric shocks to his toes, and demanded information about bombs and right-wing operatives. The legal representative of some of the arrested Boeremag members has also alleged that his clients were tortured by the police.

It would be a victory for the extreme white right if any of these allegations turn out to be true. Firstly, it could result in the acquittal of guilty accused if crucial confessions were made under duress and torture. This would be an acute embarrassment to the criminal justice system and the government, while providing a moral boost to the extreme right. Secondly, such abuses would enable the extreme right to create the martyrs they need to sustain support and enthusiasm for their cause.

\section{Coup d'état}

It would however seem that the extreme white right cannot attract sufficient popular support, nor develop the organisational capacity to execute a coup d'état. According to military analyst Rocklyn 
Williams it is vital that a number of preconditions are in place for a coup to be successful in any country (all of which are absent in respect of the South African right wing):

- A high level of political will and mass mobilisation must exist to ensure that the coup plotters possess the required levels of legitimacy and political support.

- The coup plotters need to be able to secure control over the most important of the country's strategic installations. In a country as large, complex and organised as South Africa this is close to impossible to achieve.

- The majority of the officers' corps, or a significant part thereof, need to support the objectives of the coup, and possess the political will to govern.

With every passing year since 1994 the extreme white right's chances of violently taking power, or establishing an independent Afrikaner state, have diminished. Most of the country's senior civil servants are African National Congress (ANC) appointees. The South African National Defence Force (SANDF) and South African Police Service (SAPS) have become multiracial organisations at all command levels. Moreover, many senior officers in the defence force and the police who held rightwing beliefs have been sidelined or given early retirement.

In mid-1991 some $43 \%$ of the police personnel in the former South African Police (SAP) were white. O fficers' ranks were virtually exclusively white. Even in mid-1994, some $95 \%$ of the officer corps in the SAP were white. At the end of 2002 the picture looks very different: just over a quarter $(26 \%)$ of all police personnel in the SAPS are white, and just under half $(48 \%)$ of the commissioned officers and $22 \%$ of the non-commissioned officers are white.

\section{Conclusion}

In a democracy it is not an easy task to deal effectively with a sustained terrorist threat. Civil liberties, constitutionally entrenched rights and the rule of law come at a cost when it comes to fighting terrorism: the state has to expend considerable resources and patiently collect evidence over frustratingly lengthy periods of time to successfully convict the kingpins in a closely knit terrorist network. This requires excellent teamwork between the various intelligence and law enforcement agencies, and a motivated and specialised investigating and prosecuting unit devoted to identifying and convicting terrorists.

Even more difficult to deal with is an ethnocentric and religiously inspired terrorist campaign. Such a campaign can successfully take advantage of popular grievances against the central government, and exploit ethnically based aspirations for greater political and cultural autonomy.

To crack an isolated terror cell is possible. To defeat a band of terrorists who are abetted in their actions by a growing group of sympathisers spread across large parts of the country is almost impossible. The former can be done through good police and intelligence work alone. The latter requires a political solution.

To ensure their long-term success, terrorists need the support of parts of the community in which they live. Terrorists - discounting the exceptional loner who works on his own - are members of bigger groups and gangs that provide them with logistical support and finances to further their cause. Terrorists who live and hide among people who do not cooperate with law enforcement agencies can be a state's biggest nightmare. Such a scenario must be avoided at all costs in South Africa.

\section{Endnotes}

1 J van Rooyen, Hard Right. The New White Right in South Africa, I B Tauris Publishers, London, 1994.

$2 \mathrm{H}$ Zille, The right wing in South African politics, in: P L Berger and B Godsell (eds), A Future South Africa. Visions, Strategies and Realities, Human \& Rousseau/Tafelberg, Cape Town, 1988.

3 A Snyman, Voice of a prophet, Vaandel Publishers, Mossel Bay, 1999.

This article is drawn from a forthcoming ISS monograph on the topic by Martin Schönteich and Henri Boshoff. 